\title{
The Use of Dictogloss to Teach Writing in Junior High School
}

\author{
Axel Valentino Sugondo ${ }^{1 *}$, IGA Lokita Purnamika Utami², I Nyoman Pasek \\ Hadisaputra ${ }^{3}$
}

1Prodi Bahasa Inggris, Universitas Pendidikan Ganesha, Indonesia

\section{AR T I C L E I N F O}

Article history:

Received July 16, 2021

Revised July 25, 2021

Accepted October 20, 2021

Available online November 25, 2021

Kata Kunci:

Menulis; Diktoglos; Teks deskriptif

Keywords:

Writing; Dictogloss; Descriptive Text.

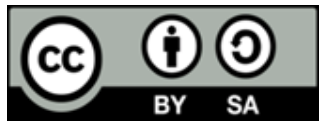

This is an open access article under the CC BY-SA license.

Copyright $(2021$ by Author. Published by Universitas Pendidikan Ganesha.

\begin{abstract}
A B S T R A K
Kondisi yang terjadi di dalam kelas adalah siswa sulit untuk menulis paragraf sederhana dalam bahasa Inggris melalui teknik menghafal. Siswa mudah lupa dan sulit menyusun poin-poin penting dalam proses menulis dengan teknik menghafal. Penelitian ini bertujuan untuk mengkaji penggunaan dictogloss dalam meningkatkan kemampuan siswa dalam menulis dan menyusun ide, khususnya dalam menulis teks deskriptif. Dalam penelitian ini digunakan penelitian tindakan kelas. Hal ini dilakukan untuk melihat peningkatan kemampuan menulis teks deskriptif siswa menggunakan dictogloss dalam proses pembelajaran. Pengumpulan data dilakukan melalui observasi dan instrumen tes. Hasil penelitian menunjukkan bahwa teknik dictogloss memotivasi siswa untuk memiliki ide yang lebih luas untuk menulis teks deskriptif mereka. Dengan meminta siswa mengerjakan tugas dalam kelompok, mereka senang menyelesaikan tugas secara bersama-sama. Mereka juga lebih baik dalam tugas individu ketika mereka mencoba mengembangkan paragraf mereka. Meskipun komponen menulis mereka masih belum cukup baik, hasil menulis mereka meningkat dari tes pra-penilaian ke tes akhir siklus. Berdasarkan permasalahan tersebut, dictogloss dapat menjadi panduan yang berguna untuk membantu siswa lebih lancar dalam menulis ide-ide mereka. Ini adalah teknik guru membacakan teks pendek kepada siswa dan siswa hanya mendengarkan. Kemudian, guru membacakan kembali teks tersebut untuk kedua kalinya dan siswa menuliskan kata kunci teks tersebut di kertas mereka, kemudian siswa membuat paragraf lengkap berdasarkan kata kuncinya.
\end{abstract}

\section{A B S T RA C T}

The condition that happened in the classroom was that the students were hardly to write a simple paragraph in English through the memorization technique. The students easily to forget and hard to arrange the key points in the process of writing with memorization technique. This study aims examine to the use of dictogloss in improving the students' ability in writing and arranging their ideas, especially in writing descriptive text. In this study, Classroom Action Research is used. It is conducted to see the improvement of students' writing ability of descriptive text using dictogloss in the learning process. A qualitative approach is a common way of conducting qualitative research. The data collection is conducted through the observation and test instruments. The results shows that the dictogloss technique motivates the students to have wider ideas to write their descriptive text. By asking the students to do the task in groups, they enjoyed to finish the given tasks together. They also did better in individual task when they tried to develop their paragraph. Although their writing components were still not good enough, their writing's result increased from pre-assessment test to post cycle test. Based on those problems, dictogloss cab be a useful guide to help the students more fluent in writing their ideas. It is a technique where the teacher reads a short text to the students, and the students just listen. Then, the teacher reads the text again for the second times, and the students write key words of the text on their paper, then the students make the full paragraph based on their key word.

\section{PENDAHULUAN}

Writing is one of four English skills other than listening, speaking, and reading (Qiu \& Lee, 2020; Tai et al., 2015). Writing is an activity to create some information or ideas into sentence or paragraph 
(Erdogan, 2019; Preus, 2012). But, to write we need some abilities to express those ideas. In writing, we need to know the patterns of the sentence, such as, tenses, passive voice, punctuation, such as using capital letter at the beginning of a sentence, using full stop or question mark in the end of the sentence, etc (Aidinlou \& Mehr, 2012; Ariyanti \& Fitriana, 2020; Lee \& Coniam, 2013). In other word writing is an activity to tell ideas and thought about something in written form (Yen et al., 2015). Writing needs to be coherent and cohesive where the all the aspect in the writing should make sense and be connected logically. Moreover, writing in this era becomes an important skill to survive globalization. Writing is used widely in every aspect, for interacting and communicating with people (Shang, 2017; Suthiwartnarueput \& Wasanasomsithi, 2012).

Based on the observations, researchers joined the class 8A in SMP Mutiara Singaraja and coincided with the subjects. The problem that occurs in relation to the activities of the English subject in this class, many of them were not able to write in English. During pre-observation activity, some factors made this problem occurred. Firstly, the students have lack of vocabulary knowledge, thus they have difficulty in arranging a sentence in writing. As a result the students feel incapable when writing in English. This is evident when teacher invited them to communicate, many of them were unable to respond and didn't understand what was being explained. In the context of education, we as a teacher can see the importance of teaching writing. To overcome the problems mentioned above, I as a researcher should find an effective way to create teaching and learning activities which include a process of interaction between the teacher and the students. Since writing is an important point, so I as the researcher used a proper technique to improve students'writing skill. The technique that I used is called "Dictogloss".

Dictogloss is a learning technique with creative activities (Pertiwi et al., 2018; Prince, 2013). Dictogloss is designed to draw the learners' attention to language form, it promotes negotiation of meaning as well as negotiation of form (R. S. Dewi, 2014; Lindstromberg et al., 2016). In this case student can discuss the task with their friends either in pair, group or other activities during the process of learning and teaching (Bani Younis \& Bataineh, 2016; E. M. Dewi, 2017). In this case I use dictogloss to help students to create descriptive texts. Dictogloss is more than just student rewrite the paragraph. Dictogloss stand for the words "dictation" and "glossary". Dictation is when one person reads a text aloud and the audience writes what it said (Ajmal et al., 2020; Calzada \& Mayo, 2021). Glossary is a list of words with its meaning. Dictogloss is designed to draw the learners' attention to language form, dictogloss promotes negotiation of meaning as well as negotiation of form. Students can discuss the material that teach by the teacher with their friends during the learning and teaching process (Sari \& Adnan, 2013; Vasiljevic, 2010). Dictogloss has four specific steps: preparation stage, dictation stage, rewriting stage and analysis and correction stage.

Students' writing competency is a process which is achieved in writing to inform the message clearly. There is problems of this study that can be found by the researcher, such as the students' writing competency of English was low. Students in SMP Mutiara Singaraja was taught by memorization technique but they can't make a significant improvement on their writing subject. So the researcher will try dictogloss technique on writing skill. Because of the difficulty faced by the students at grade eight of SMP Mutiara in writing English, the focus of this research is on the use of dictogloss in improving the students' ability in writing and arranging their ideas, especially in writing descriptive text.

\section{METODE}

In this study, Classroom Action Research is used. There are four steps in conducting an action research. Those four steps are (1) planning, (2) acting, (3) observing, and (4) reflecting. This classroom action research was carried out in two cycles, and the procedure of this study include four stages: planning, implementing, observing, and reflecting. Before conducting procedures of the classroom action research, it is started by conducting preliminary test. It is conducted to see the improvement of students' writing ability of descriptive text using dictogloss in the learning process. A qualitative approach is a common way of conducting qualitative research. Classroom Action Research is about the sequence of teaching and learning process that happens in the class. One "cycle" indicates a group of event needed to be conducted before managing another "cycle". The reflection of the previous study is needed as the correction to prepare the next action. Conducting action research needs educators with a skill to reflect on one's own teaching practices and engage in self-directed learning, with the ultimate goal of improving student learning. To reach optimal learning, teachers must build their knowledge of student learning and intentionally study the instructional practices they are implementing in the classroom (Rawlinson \& Little, 2004: 24). Therefore, classroom action research is applied to get students' motivation process become well to get the best result while they start studying, in the middle of the learning and also in the end of study. The data collection is conducted through the following instruments. Observation, aims to analyze 
and manage each student's behavior in classroom during teaching and learning process. Test, was conducted four times in this research. The first was the pre-assessment to see their ability in writing. The other two tests were conducted while the dictogloss was applied in the learning and teaching process and the last one was conducted to check students' understanding in writing descriptive text by using dictogloss.

\section{HASIL DAN PEMBAHASAN}

Hasil

Preliminary test result showed that the data that is showed 6 students passed the test and 23 students others failed on the test. The details can be seen in Table 1.

Table 1. Writing Score in Preliminary Study

\begin{tabular}{cccc}
\hline No & Score level & Category & Number \\
\hline 1 & $0-49$ & Very poor & 7 \\
2 & $50-69$ & Poor & 16 \\
3 & $70-79$ & Fair & 1 \\
4 & $80-89$ & Good & 3 \\
5 & $90-100$ & Very good & 2 \\
\hline
\end{tabular}

Based on the data, the researcher found that there were $13 \%$ students who got $0-49$ and 16 or 55 , $17 \%$ students who got 50- 69 . On the other hand, there were 1 students or 3,44\% of students' total got 7079 , there were 3 students or $10,34 \%$ of students' total got $80-89$, and there were 2 students or $6,89 \%$ of students' total got 90-100. So, most of them cannot answer correctly the preliminary test that given by the researcher. After giving the preliminary test, the researcher implemented the classroom action research to the students which is consists of two cycles: cycle 1 and cycle 2 . The cycle in classroom action research presents in 4 stages; planning, implementing, observing and reflecting.

Cycle 1 was carried out from Monday, September 9th to Friday, September 20th, 2019. It was conducted in two main meetings. First meeting was done on September 9th, 2019, and second meeting was September 13rd, 2019, in this meeting the researcher conducted test for cycle I. On Saturday, September 7th, 2017, the researcher discussed with the collaborator teacher (English teacher) about using dictogloss technique conducted the classroom action research. The researcher prepared the instruments before conducting classroom action research. The researcher conducted planning in meeting and the cycle. First, the researcher made the lesson plan as the guidelines for the researcher for conducting the teaching activity. The lesson plan was arranged based on syllabus in the first semester. The lesson plan consists of; identity, competency standard, basic competency, indicators, the purpose of the study, material, method, teaching and learning activity, media and reference, and assessment. The material was prepared by researcher. The researcher prepared the text for discussion in the teaching and learning process and gave work sheet for the students which consists of questions that should be answered by the students. The researcher also used media to deliver the material. The media were white board, copy of material and the text.

The teacher implementing dictogloss technique to teaching writing comprehension into some steps, there are (1) teacher started the lesson with brainstorming to activate the students' brain about the topic of the lesson. The teacher gave the descriptive text to the students. After that, (2) the teacher gave question which related to the descriptive text. This activity was brainstorm activities were done by asking and answering questions. (3) Then the teacher introduced the topic of the lesson which would be discussed. (4) The teacher showed the text to explain. The teacher taught and repeated as teaching technique by using dictogloss. (5) The teacher read the text and asked to the class what the text was. (6) The students tried to look up their dictionaries and their partner to guess what the text was. When the students got the answer, (7) the teacher repeated the word and asked to the students to repeat it.

The students were still passive and did not interest in learning English when they were taught by using dictogloss. Concepts related to descriptive text was then explained, however, few students pay attention to the learning process. Finally, the researcher gave a chance for the students to ask some questions about the topic, but the class still crowded because some students did not give attention of the teacher to explain, then the teacher gave motivation to the students to learn the material again at home.

In the second meeting, teacher greeted the students when he entered the classroom. Then, he checked the students' attendance list. When the researcher began to teach in class, the students kept silent and gave attention, although the class rather crowded just a little. After greeting and asking the students' 
preparation for the test, the researcher wanted to know whether there were students who were absent in the meeting and all students were present. In this meeting the teacher gave the test for cycle I. The researcher gave the instruction about procedure of doing this test. Then he started by giving a question sheet with descriptive text. The researcher gave 45 minutes to do the test.

Actually, the students enjoyed teaching learning process, but some of them did not pay attention what the teacher said. Furthermore, there were two or more students were just silent. They also could not absorb the material well. Some said they were afraid of the teacher and the lesson. Some of them thought that English was difficult; the words on English were strange. Based on the observation and the implementation of cycle 1 the researcher needs improvement as in explaining and socializing dictogloss to the students. Thus, the students will pay more attention and will not be crowded during the teaching learning activity. To see whether or not the action was successful, the researcher who observed the process of the teaching and learning process in the classroom made a reflection. The reflection focused on the analysis of the teaching and learning process and learning results.

From the data, the teacher asked the English teacher to discuss together about the problem that the students most faced in the class and tried to find out the way out by changing the writing learning model used to improve the students' writing skill in order to the teaching learning process success. The improvement for cycle 2 the researcher asked the students to form group discussion consist three students in every group. The students must answer the question given by the teacher. So by changing the teaching model, the teacher hope that the changing model can improve students writing ability.

Table 2. Writing Score in Cycle 1

\begin{tabular}{cccc}
\hline No & Score level & Category & Number \\
\hline 1 & $0-49$ & Very poor & 1 \\
2 & $50-69$ & Poor & 0 \\
3 & $70-79$ & Fair & 4 \\
4 & $80-89$ & Good & 15 \\
5 & $90-100$ & Very good & 9 \\
\hline
\end{tabular}

Based on Table 2, the researcher found that $3.44 \%$ of students got very bad, $0 \%$ of students got bad, $13,79 \%$ of students got enough, $51,72 \%$ of students got good, and $31,03 \%$ of students got very good. The mean of the data are 81.03. The meadian of the data are 80 . The mode of the data are 80 and the standar deviation for the data are 11,131. The category of the data based on analytic scale for rating composition task.

The planning at second cycle was almost the same as the first cycle. The description are below: Cycle 2 was conducted on September 16thand 20th, 2019. This cycle was an improvement from cycle 1 because in the last cycle the researcher had found weaknesses. So, it was needed to do the second cycle. The researcher hoped in cycle II, all students could be more active and be able to completely understand the material, and could increase the students' score in writing. Like usual, the researcher asked the chief of the class to lead praying and then check the students' presence. Before beginning the procedure, the researcher reviewed the material presented at the previous meeting and also gave them know the result of writing test. The researcher tried to give the concepts about the topic discussed. Not forget, he designed lesson plan. The researcher collaborated with the English teacher to solve the students' problems. The result of discussion is the researcher changed the learning model by grouping the students into group consists of three students and they must be answer the teacher's questions, so students give more attention and get the motivation for learning writing text.

The researcher did his classroom action research on September 16th and September 20th, 2019 at $07.00-08.20 \mathrm{AM}$ ). Thus, the researcher had two meeting in the second cycle. The researcher as the teacher came to class. Then teacher greeted the students when he entered the classroom. Then, he checked the students' attendance list. When the researcher began to teach in class, the students kept silent and gave attention, although the class rather crowded. The teacher started the lesson with brainstorming to activate the students' brain about the topic of the lesson. The teacher gave the descriptive text to the students. After that, the teacher gave question which related the descriptive text. This activities is brainstorm activities were done by asking and answering questions. Then the teacher introduced the topic of the lesson which would be discussed. In front of the class, the teacher displayed text to re-explain the dictogloss. The teacher instructed and repeated the concepts. The researcher displayed the student's writing score from the previous test as well as their areas of weakness. The researcher expected that by exposing their flaws, they would change and become more active.

In this meeting the teaching learning model has been changed. The teacher ask the students to forming the group discussion with their friends. The teacher ask the students to discuss about the 
materials that given by teacher, then the teacher gave question to every group. By using this model the almost the students silent and giving attention with the teacher. They try to answers by discussing. If the students cannot anwer the question by the teacher, the teacher will give question with the other group. Every group which can answer the question by the teacher will get the point. It is can making the students interest to more writing material. They challenged to answers the question by the teacher to get more points.

This was the last meeting for cycle 2. The researcher would gave the test to the students. But before doing the test, he did not forget to greet and ask the students' preparation and also check whether there was absent that day. And all students were present. Then researcher gave the instruction about procedure of doing this test. Then the researcher started by giving a work sheet. He gave 30 minutes to do the test. Finally, he concluded the lesson by motivating the students and thanking them for their cooperation, and he hoped that all of the students received satisfactory results on this test. In cycle II, the researcher saw that the students enjoyed with teaching and learning process. They had fun with the technique and the material. Thus, they were able to absorb the material more easily, and they were no longer afraid to express their ideas or opinions to their friends, despite making some mistakes. They had a great motivation to learn the material well. But, there were some of the students still confusion or they just made a noisy and joked with their friend. This reflection focused on the students' improved writing skills as a result of using the dictogloss technique.

The achievement score were compared to the success criteria, and this could be used to identify the improvement. The students were actively involved during the teaching and learning process. This could be seen from the students' participation in every part of this technique. The teaching learning process could run well because the researcher as the English teacher had been able to solve some obstacles both from the students and the researcher as the English teacher. For detail score in cycle 2 can be seen in Table 3.

Table 3. Writing Score in cycle 2

\begin{tabular}{cccc}
\hline No & Score level & Category & Number \\
\hline 1 & $0-49$ & Very poor & 0 \\
2 & $50-69$ & Poor & 0 \\
3 & $70-79$ & Fair & 5 \\
4 & $80-89$ & Good & 9 \\
5 & $90-100$ & Very good & 15 \\
\hline
\end{tabular}

Based on table, the mean of the data are 84,8 . The meadian of the data are 90 . The mode of the data are 80 and the standar deviation for the data are 9,5.

Tabel 4. The Comparison of Students' Writing Score in Pre Test, Cycle 1, and Cycle 2

\begin{tabular}{ccccc}
\hline No & Score level & \multicolumn{3}{c}{ Number of Students } \\
\hline & & Pretest & Cycle 1 & Cycle 2 \\
1 & $0-49$ & 7 & 1 & 0 \\
2 & $50-69$ & 16 & 0 & 0 \\
3 & $70-79$ & 1 & 0 & 5 \\
4 & $80-89$ & 3 & 4 & 9 \\
5 & $90-100$ & 2 & 15 & 15 \\
\hline
\end{tabular}

Based on the results of the previous two cycles, the data indicated that using the dictogloss technique could improve students' writing skills and influence students' motivation. The students more active, interesting with the material and pay attention with the teacher in learning process. It could be seen by the mean of each cycles. The trend of the data was increasing each steps from 54,6 to 81 and for the final cycle 84.8. By observation in the preliminary study, the researcher found that the main problems of writing were lack of variety of techniques used by the teacher during the teaching and learning process and students' motivation. The researcher implemented the dictogloss technique in cycle 1 after learning from those problems, and he thoroughly prepared all materials required.

As a result, the students were interested in participating in all of the steps of this technique and could be active, but two or more students remained silent and joked with their friends due to their nature. 
So, in cycle 2, the researcher satisfied with the result, because student's writing mastery were increase after taught by using dictogloss.

The effective procedure in teaching writing of the first year student of SMP Mutiara Singaraja using dictogloss was succeed. It is indicated from 70.00 mean score gained in the test. So, they succeeded to gain the target of Minimum Mastery Criteria in writing. With explanation is 5 student or $17,24 \%$ was in category fair, 9 students or 31,03\% were in category good, and 15 students or $51,72 \%$ students were in category very good. The conclution that using dictogloss could improve writing comprehension was succesfull.

\section{Pembahasan}

Writing is one of four English skills other than listening, speaking, and reading (Qiu \& Lee, 2020; Tai et al., 2015). Writing is an activity to create some information or ideas into sentence or paragraph (Erdogan, 2019; Preus, 2012). But, to write we need some abilities to express those ideas. In writing, we need to know the patterns of the sentence, such as, tenses, passive voice, punctuation, such as using capital letter at the beginning of a sentence, using full stop or question mark in the end of the sentence, etc (Aidinlou \& Mehr, 2012; Ariyanti \& Fitriana, 2020; Lee \& Coniam, 2013). In other word writing is an activity to tell ideas and thought about something in written form (Yen et al., 2015). Writing needs to be coherent and cohesive where the all the aspect in the writing should make sense and be connected logically. Moreover, writing in this era becomes an important skill to survive globalization. Writing is used widely in every aspect, for interacting and communicating with people (Shang, 2017; Suthiwartnarueput \& Wasanasomsithi, 2012).

Dictogloss is a learning technique with creative activities (Pertiwi et al., 2018; Prince, 2013). Dictogloss is designed to draw the learners' attention to language form, it promotes negotiation of meaning as well as negotiation of form (R. S. Dewi, 2014; Lindstromberg et al., 2016). In this case student can discuss the task with their friends either in pair, group or other activities during the process of learning and teaching (Bani Younis \& Bataineh, 2016; E. M. Dewi, 2017). In this case I use dictogloss to help students to create descriptive texts.Dictogloss is more than just student rewrite the paragraph. Dictogloss stand for the words "dictation" and "glossary". Dictation is when one person reads a text aloud and the audience writes what it said (Ajmal et al., 2020; Calzada \& Mayo, 2021). Glossary is a list of words with its meaning. Dictogloss is designed to draw the learners' attention to language form, dictogloss promotes negotiation of meaning as well as negotiation of form. Students can discuss the material that teach by the teacher with their friends during the learning and teaching process (Sari \& Adnan, 2013; Vasiljevic, 2010). Dictogloss has four specific steps: preparation stage, dictation stage, rewriting stage and analysis and correction stage. They student were easy to arrange sequence of the text. So they can easily write a sentences in a good order.

\section{SIMPULAN}

The descriptive writing achievement of eighth-year students at SMP Mutiara Singaraja in the $2019 / 2020$ academic year improved after they were taught using the dictogloss technique. The data presented proved this.In the pre-assessment, the mean or average score of students' writing achievement was 55.50. In the first cycle, it improved to 81.01, and in the second cycle, it improved to 84.82. The dictogloss technique motivates the students to have wider ideas to write their descriptive text. By asking the students to do the task in groups, they enjoyed to finish the given tasks together. They also did better in individual task when they tried to develop their paragraph. Although their writing components were still not good enough, their writing's result increased from pre-assessment test to post cycle test. Referring to the analysis and the conclusions above, some suggestions offered are as follows: English teachers should be well prepared and have good time management skills in order to achieve better results when using the dictogloss technique to teach writing; English teachers should pay close attention to the entire class to ensure that all students comprehend the material. Review is an important session that English teachers should conduct at the end of the teaching and learning activities to assess the students' understanding of the given materials. The descriptive writing achievement of the eighth year students of SMP Mutiara Singaraja in the academic year of 2019/2020 improved after they have been taught by using dictogloss technique. It was proven by the data shown. The mean or the average score of students" writing achievement in the pre-assessment was 55.50. It improved to 81.01 in the first cycle and 84.82 in the second cycle. The dictogloss technique motivates the students to have wider ideas to write their descriptive text. By asking the students to do the task in groups, they enjoyed to finish the given tasks together. They also did better in individual task when they tried to develop their paragraph. 


\section{DAFTAR RUJUKAN}

Aidinlou, N. A., \& Mehr, H. S. (2012). The Effect of Discourse Markers Instruction on EFL Learners' Writing. World Journal of Education, 2(2), 10-16. https://eric.ed.gov/?id=EJ1158965.

Ajmal, M., Iqbal, I., Mahmood, R., \& Zafar, A. (2020). The Effectiveness of Using Dictogloss Technique to Improve Students' Writing: A Case Study from University of Lahore. Dilemas Contemporáneos: Educación, Política y Valores, 7(2).

Ariyanti, \& Fitriana, R. (2020). EFL Students Perception on Mendeley Reference Manager in Thesis riting. International Conference on Business, Law, and Pedagogy. https://doi.org/10.4108/eai.16-102019.163223.

Bani Younis, R., \& Bataineh, R. (2016). To Dictogloss or Not to Dictogloss: Potential Effects on Jordanian EFL Learners' Written Performance. Apples: Journal of Applied Language Studies, 10. https://jyx.jyu.fi/handle/123456789/51811.

Calzada, A., \& Mayo, M. D. P. G. (2021). Effects of Proficiency and Collaborative Work on Child EFL Individual Dictogloss Writing. Language Teaching for Young Learners, 3(2), 246-274. https://doi.org/10.1075/ltyl.20003.ca.

Dewi, E. M. (2017). Improving Students' Grammar using Dictogloss. English Education Journal, 8(3), 352366. http://e-repository.unsyiah.ac.id/EEJ/article/view/8923.

Dewi, R. S. (2014). Teaching Writing throught Dictogloss. IJEE (Indonesian Journal of English Education), 1(1), 65-76. http://jornal.uinjkt.ac.id/index.php/ijee/article/view/1195.

Erdogan, V. (2019). Integrating 4C Skills of 21st Century into 4 Language Skills in EFL Classes Vacide Erdoğan. International Journal of Education and Research, 7(11), 113-124.

Lee, I., \& Coniam, D. (2013). Introducing Assessment for Learning for EFL Writing in an Assessment of Learning Examination-Driven System in Hong Kong. Journal of Second Language Writing, 22(1), 34-50. https://doi.org/10.1016/j.jslw.2012.11.003.

Lindstromberg, S., Eyckmans, J., \& Connabeer, R. (2016). A Modified Dictogloss for Helping Learners Remember L2 Academic English Formulaic Sequences for use in Later Writing. English for Specific Purposes, 41, 12-21. https://www.sciencedirect.com/science/article/pii/S0889490615000447.

Pertiwi, D., Ngadiso, N., \& Drajati, N. A. (2018). The Effect of Dictogloss Technique on the Students' Writing Skill. Studies in English Language and Education, 5(2), 279-293. http://www.jurnal.unsyiah.ac.id/SiELE/article/view/11484.

Preus, B. (2012). Authentic Instruction for 21st Century Learning: Higher Order Thinking in an Inclusive School. American Secondary Education, 40(3), 59-79.

Prince, P. (2013). Listening, Remembering, Writing: Exploring the Dictogloss Task. Language Teaching Research, 17(4), 486-500. https://doi.org/10.1177/1362168813494123.

Qiu, X., \& Lee, M. K. (2020). Regulated Learning and Self-Efficacy Beliefs in Peer Collaborative Writing: An Exploratory Study of L2 Learners' Written Products, Task Discussions, and Self-Reports. System, 93, 102312. https://doi.org/10.1016/j.system.2020.102312.

Sari, E. J., \& Adnan, A. (2013). The use of Dictogloss Method in Teaching Listening a Hortatory Exposition Text at Senior High School. Journal of English Language Teaching, 2(1), 50-58. http://ejournal.unp.ac.id/index.php/jelt/article/view/2588.

Shang, H. F. (2017). An Exploration of Asynchronous and Synchronous Feedback Modes in EFL Writing. Journal of Computing in Higher Education, 29(3), 496-513. https://doi.org/10.1007/s12528-0179154-0.

Suthiwartnarueput, T., \& Wasanasomsithi, P. (2012). Effects of using Facebook as a Medium for Discussions of English Grammar and Writing of Low-Intermediate EFL Students. Electronic Journal of Foreign Language Teaching, 9(2), 194-214.

Tai, H. C., Lin, W. C., \& Yang, S. C. (2015). Exploring the Effects of Peer Review and Teachers' Corrective eedback on EFL Students' Online Writing Performance. Journal of Educational Computing Research, 53(2), 284-309. https://doi.org/10.1177/0735633115597490.

Vasiljevic, Z. (2010). Dictogloss as an Interactive Method of Teaching Listening Comprehension to L2 Learners. English Language Teaching, 3(1), 41-52. https://eric.ed.gov/?id=EJ1081435.

Yen, Y. C., Hou, H. T., \& Chang, K. E. (2015). Applying Role-Playing Strategy to Enhance Learners' Writing and Speaking Skills in EFL Courses using Facebook and Skype as Learning Tools: a Case Study in Taiwan. Computer Assisted Language Learning, 28(5), 383-406. https://doi.org/10.1080/09588221.2013.839568. 